\title{
Klaudia Celińska
}

Uniwersytet Marii Curie-Skłodowskiej w Lublinie

klaudia.anna.celi@gmail.com

\section{Wywłaszczenie nieruchomości - aspekty prawne}

\author{
Expropriation of Real Estate - Selected Law Aspects
}

\begin{abstract}
STRESZCZENIE
Opracowanie zawiera analizę środka prawnego, jakim jest wywłaszczenie nieruchomości. Ponadto została wskazana istota zastosowania wywłaszczenia, procedura wywłaszczeniowa oraz aspekt odszkodowania za wywłaszczenie na rzecz osoby wywłaszczonej. Analiza prawna jest oparta na wykładni art. 21 Konstytucji RP oraz ustawy z dnia 21 sierpnia 1997 r. o gospodarce nieruchomościami. Celem artykułu jest omówienie aspektów prawnych i specyfiki tytułowej instytucji prawnej, a także zwrócenie uwagi na zastosowanie jej w praktyce. Autorka we wstępie przedstawia pojęcie wywłaszczenia w rozumieniu prawa krajowego i międzynarodowego. Analiza w szczególności obejmuje przesłanki jego zastosowania przez uprawnione podmioty.
\end{abstract}

Słowa kluczowe: wywłaszczenie nieruchomości; decyzja administracyjna; starosta; Skarb Państwa; rozprawa administracyjna

\section{WSTĘP}

Na gruncie przepisów szczególnych ustawy z dnia 21 sierpnia 1997 r. o gospodarce nieruchomościami ${ }^{1}$ wywłaszczenie jest pojęciem stworzonym tylko w zakresie prawa własności, użytkowania wieczystego, a także innych praw rzeczowych na nieruchomościach. Wywłaszczenie to specjalny środek prawny, ponieważ jego przedmiotem są tylko nieruchomości położone na obszarach przeznaczonych na podstawie miejscowych planów zagospodarowania przestrzennego na cele publiczne lub dla przyszłych inwestycji o tym samym charakterze. Nabywcą takiej nieruchomości w drodze wywłaszczenia jest tylko i wyłącznie Skarb Państwa lub jednostka samorządu terytorialnego. 
Art. 122 u.o.g.n. definiuje pojęcie wywłaszczenia nieruchomości jako czynność polegającą na pozbawieniu albo ograniczeniu w drodze decyzji prawa własności, prawa użytkowania wieczystego lub innego prawa rzeczowego na nieruchomości. Pojęcie to zostało wprowadzone do Konstytucji z dniem 31 grudnia 1989 r., czyli tego samego dnia, kiedy weszła w życie ustawa z dnia 29 grudnia 1989 r. o zmianie Konstytucji Rzeczypospolitej Ludowej ${ }^{2}$. Ponadto Konstytucja Rzeczypospolitej Polskiej z dnia 2 kwietnia 1997 r. $^{3}$ nie definiuje już wywłaszczenia, a jedynie stanowi w art. 21, że wywłaszczenie jest dopuszczalne tylko wtedy, gdy dokonuje się go na cele publiczne i za słusznym odszkodowaniem osoby wywłaszczonej.

Dodatkowo warto zwrócić uwagę na prawnomiędzynarodowe rozumienie pojęcia wywłaszczenia, które nie ma swojej definicji legalnej. Jest ono natomiast szerzej rozumiane niż w wyżej przytoczonych przepisach. W obrocie prawnomiędzynarodowym wywłaszczenie to odebranie prawa indywidualnego przez państwo. Obejmuje ono swym zakresem szeroki katalog otwarty dóbr chronionych, takich jak prawa autorskie, patenty i inne ${ }^{4}$. Pojęcia, o którym mowa, nie używa się w art. 1 Protokołu nr 1 z dnia 20 marca 1952 r. do Konwencji z dnia 4 listopada 1950 r. o ochronie praw człowieka i podstawowych wolności ${ }^{5}$, ale należy zaznaczyć, że podana regulacja stanowi tylko, że „każda osoba fizyczna i prawna ma prawo do poszanowania swego mienia. Nikt nie może być pozbawiony swojej własności, chyba że w interesie publicznym i na warunkach przewidzianych przez ustawę oraz zgodnie z ogólnymi zasadami prawa międzynarodowego".

Jak przedstawiono powyżej, definicja wywłaszczenia nie jest precyzyjna i jednolita, lecz w Konstytucji RP, ustawach szczególnych czy w obrocie prawnomiędzynarodowym jej przesłanki i znaczenie są takie same.

\section{ISTOTA I PRZEDMIOT WYWŁASZCZENIA}

Wywłaszczenie jest pozbawieniem lub ograniczeniem, w drodze konstytutywnej decyzji administracyjnej, prawa własności, prawa użytkowania wieczystego lub innego prawa rzeczowego na nieruchomości. Jest to znaczenie wąskie tego pojęcia, wynikające wprost z art. 112 i n. u.o.g.n. Analogicznie można wywnioskować, że jest to ograniczenie praw właściciela nieruchomości, która podlega wywłaszczeniu. Ta instytucja prawna jest jednym z najbardziej skrajnych przykładów ingerencji

2 Ustawa z dnia 29 grudnia 1989 r. o zmianie Konstytucji Rzeczypospolitej Ludowej (Dz.U. nr 75, poz. 444 ze zm.).

3 Dz.U. z 1997 r., nr 78, poz. 483, dalej jako: Konstytucja RP.

4 M. Szalewska, Wywłaszczenie nieruchomości, Torun 2005, s. 124.

5 Dz.U. z 1995 r., nr 36, poz. 175 ze zm. 
państwa w wykonywanie prawa własności ${ }^{6}$. Oznacza to, że zakres prawa rzeczowego, pozwalający na używanie nieruchomości zgodnie z własną wolą i z wyłączeniem innych osób, w określony przez prawo sposób zostaje ograniczony lub odebrany potencjalnemu właścicielowi nieruchomości. Taki zabieg jest ingerencją państwa w samą istotę prawa własności, użytkowania wieczystego czy innego prawa rzeczowego na nieruchomości.

Rozumienie pojęcia wywłaszczenia nieruchomości jest ujęte w znaczeniu szerokim w Konstytucji RP. Doktryna uznaje, że Konstytucja RP posługuje się pojęciem własności $\mathrm{w}$ dwojakim znaczeniu, tzn. prywatnoprawnym $\mathrm{w}$ art. 64 ust. 1 i 2 , czyli o prawie do własności, innych prawach majątkowych oraz prawie dziedziczenia i ograniczeniu własności w tym znaczeniu, a ponadto określa ogólne pojęcie „własność” w rozumieniu „majątek” pisie art. 64 ust. 3 Konstytucja RP stanowi, że „własność może być ograniczona tylko $\mathrm{w}$ drodze ustawy i tylko $\mathrm{w}$ zakresie, $\mathrm{w}$ jakim nie narusza ona istoty prawa własności”, stosownie do art. 31 ust. 3, który wskazuje na to, że „ograniczenia w zakresie korzystania z konstytucyjnych wolności i praw mogą być ustanawiane tylko w ustawie i tylko wtedy, gdy są konieczne w demokratycznym państwie dla jego bezpieczeństwa lub porządku publicznego, bądź dla ochrony środowiska, zdrowia i moralności publicznej, albo wolności i praw człowieka".

Wywłaszczenie polega wprost na odebraniu uprawnień właściciela dotyczących posiadania, korzystania i rozporządzania nieruchomością. Art. 21 ust. 2 Konstytucji RP przewiduje, że zastosowanie tego środka prawnego może mieć miejsce na obszarach przeznaczonych $\mathrm{w}$ miejscowych planach zagospodarowania przestrzennego na cele publiczne, obejmujących w swoim zakresie daną nieruchomość jako niezbędną do zrealizowania tego celu. Przepis ten jasno wskazuje na granice dozwolonej ingerencji państwa w prawo do nieruchomości właściciela ${ }^{8}$. W przypadku, kiedy cel publiczny został osiągnięty, możliwość wydania decyzji ex post o wywłaszczeniu nieruchomości jest niedopuszczalna, ponieważ brak jest przesłanek ustawowych do jej podjęcia. Taka decyzja może umożliwić podjęcie tylko niezbędnych w tym zakresie przyszłych działań inwestora9 9

Dla prawidłowej analizy pojęcia wywłaszczenia wskazane jest przytoczenie kodeksowej definicji nieruchomości, uregulowanej w art. $46 \S 1$ ustawy z dnia 23 kwietnia 1964 r. - Kodeks cywilny ${ }^{10}$, według którego „nieruchomościami są części powierzchni ziemskiej stanowiące odrębny przedmiot własności (grunty), jak

6 S. Jarosz-Żukowska, Konstytucyjna zasada ochrony własności, Kraków 2003, s. 229.

7 T. Woś, Wywłaszczenie nieruchomości i ich zwrot, Warszawa 2011, s. 29.

8 E. Stefańska, [w:] S. Babiarz, Nieruchomości w prawie cywilnym, administracyjnym i podatkowym, t. 2, Warszawa 2017, s. 773.

9 Wyrok WSA w Rzeszowie z dnia 6 grudnia 2012 r., II SA/Rz 826/12, LEX nr 134272.

10 Dz.U. z 2017 r., poz. 459, 933, 1132; Dz.U. z 2018 r., poz. 398, dalej jako: k.c. 
również budynki trwale z gruntem związane lub części takich budynków (lokale), jeżeli na mocy przepisów szczególnych stanowią odrębny od gruntu przedmiot własności”. Ta definicja legalna została częściowo powtórzona w ustawie o gospodarce nieruchomościami, z zaznaczeniem, że nieruchomość gruntowa to grunt wraz z częściami składowymi, z wyłączeniem budynków i lokali, jeżeli stanowią one odrębny przedmiot własności ${ }^{11}$.

Należy zaznaczyć, że przepisy u.o.g.n. nie definiują pojęcia nieruchomości w rozumieniu k.c., zawierają one jedynie definicję ustawową nieruchomości gruntowej. Z obu definicji legalnych - zarówno tej uregulowanej na gruncie Konstytucji RP, jak i u.o.g.n. - można wywnioskować, że nieruchomościami są i grunty niezabudowane, i grunty zabudowane, a ponadto mogą nimi być budynki i lokale, jeżeli na mocy przepisów szczególnych stanowią odrębny od gruntu przedmiot własności, co należy rozumieć w ten sposób, że właściciele tych budynków i lokali nie są jednocześnie właścicielami gruntu ${ }^{12}$. Dodatkowo trzeba zaznaczyć, że prawo własności dotyczy wymiaru przestrzennego nieruchomości i obejmuje to, co znajduje się pod gruntem i nad nim. Obie definicje nieruchomości pokazują, jak obszerne jest to pojęcie, czyli w rzeczywistości - przedmiot wywłaszczenia.

\section{PRZESŁANKI WYWŁASZCZENIA NIERUCHOMOŚCI}

Wywłaszczenie nieruchomości może być dokonane, jeżeli jest ono niezbędne do zrealizowania celu publicznego, a osiągnięcie tego celu jest niemożliwe w inny sposób. Ustawowe pojęcie celu publicznego reguluje art. 6 u.o.g.n. Jest to np. wydzielenie gruntów pod drogi publiczne, budowa i utrzymanie urządzeń służących ochronie środowiska, opieka nad zabytkami, zakładanie i utrzymywanie cmentarzy czy też ustanawianie miejsc na ochronę przyrody. Katalog celów publicznych określa ustawowe przesłanki warunkujące wydanie decyzji o wywłaszczeniu zgodnej z prawem. W art. 2 pkt 5 ustawy z dnia 27 marca 2003 r. o planowaniu i zagospodarowaniu przestrzennym ${ }^{13}$ ustawodawca wprowadził także częściową definicję inwestycji celu publicznego. Jest to działanie o znaczeniu gminnym, powiatowym, wojewódzkim, krajowym oraz metropolitalnym, bez względu na status podmiotu podejmującego te działania oraz źródła ich finansowania, stanowiące realizację celów, o których mowa w art. 6 u.o.g.n. Pomimo definicji ustawowej celów publicznych należy zachować szczególną ostrożność, na co zwrócił uwagę w orzecznictwie Naczelny Sąd Administracyjny. W wyroku z dnia 12 grudnia 2017 r. NSA orzekł, że:

\footnotetext{
${ }^{11}$ R. Strzelczyk, Prawo nieruchomości, Warszawa 2016.

12 Ibidem.

${ }^{13}$ Dz.U. z 2017 r., poz. 1073, 1566, dalej jako: u.o.p.z.p.
} 
[...] nie można przyjmować automatycznie, że każda inwestycja związana z budową [...] służy celom publicznym - interesowi publicznemu. Istotą inwestycji celu publicznego jest jej nakierowanie na urzeczywistnienie interesu publicznego, istotnego dla zbiorowości, przynajmniej na poziomie lokalnym. Inwestor powołujący się na cel publiczny powinien być gotowy na wykazanie, że jego realizacja nie stanowi zaspokojenia interesu prywatnego indywidualnego bądź grupowego ${ }^{14}$.

Ponadto sama etymologia celu publicznego tłumaczy, że musi on dotyczyć ogółu ludzi, służyć ogółowi i być dostępny dla wszystkich.

\section{PODMIOTY I SPECYFIKA WYWŁASZCZENIA}

Należy podkreślić, że każda nieruchomość może być wywłaszczona pod inwestycje publiczne tylko i wyłącznie na rzecz Skarbu Państwa albo jednostki samorządu terytorialnego. Nieruchomość nie może być wywłaszczona, jeżeli stanowi własność państwową, z wyjątkiem sytuacji, gdy chodzi o wywłaszczenie prawa użytkowania wieczystego lub ograniczonych praw rzeczowych obciążających nieruchomość ${ }^{15}$. Specyfiką tej instytucji prawnej jest to, że może nim zostać objęta cała nieruchomość albo jej część.

Ponadto art. 113 ust. 3 u.o.g.n. wprost wskazuje na przypadek objęcia uprawnieniem części nieruchomości, kiedy pozostała część nie nadaje się do prawidłowego wykorzystywania na dotychczasowe cele. Wówczas na żądanie właściciela lub użytkownika wieczystego nieruchomości nabywa się tę część w drodze umowy na rzecz Skarbu Państwa lub na rzecz jednostki samorządu terytorialnego. Przepis ten stanowi instrument zabezpieczający interesy właściciela, któremu w drodze wywłaszczenia została tylko część nieruchomości. W takiej sytuacji przyznaje się mu roszczenie oparte na analizie skutków decyzji wywłaszczeniowej, a za kryterium oceny tej analizy ustawodawca przyjął to, czy pozostała część nieruchomości nadaje się do wykorzystania na dotychczasowe cele.

Orzecznictwo wyjaśnia, że dla uniknięcia dowolności w ocenie należy się odnieść do rzeczywistego przeznaczenia nieruchomości ${ }^{16}$. Organem właściwym w sprawie o wywłaszczenie jest starosta jako wykonujący zadania z zakresu administracji rządowej. Wszczęcie postępowania wywłaszczeniowego musi natomiast zostać poprzedzone rokowaniami zmierzającymi do zawarcia umowy cywilnoprawnej nabycia nieruchomości z właścicielem lub użytkownikiem wieczystym,

${ }_{14}$ Wyrok NSA - OZ w Krakowie z dnia 12 grudnia 2017 r., II SA/Kr 1010/00, ONSA 2001, nr 4, poz. 186.

${ }^{15}$ E. Stefańska, op. cit., s. 775.

16 Wyrok SN z dnia 2 lutego 2012 r., II CSK 265/11, LEX nr 1131118. 
a także z osobą, której przysługuje ograniczone prawo rzeczowe do nieruchomości będącej przedmiotem wywłaszczenia. Co do ostatniego wymienionego podmiotu, a mianowicie osoby, której przysługuje ograniczone prawo rzeczowe do nieruchomości, istotne będzie wskazanie orzecznictwa sądu administracyjnego. W wyroku WSA w Kielcach wskazano, że samoistne posiadanie nieruchomości nie może być traktowane jako stan prawny, ponieważ przyjmuje się, że posiadanie jest cechą stanu faktycznego. W związku z powyższym posiadacz nieruchomości, który nie legitymuje się interesem prawnym, lecz faktycznym, nie ma uprawnień do udziału $\mathrm{w}$ charakterze strony w postępowaniu wywłaszczeniowym ${ }^{17}$. Jeżeli wywłaszczeniu podlega nieruchomość o nieuregulowanym stanie prawnym, która nie ma żadnego zbioru dokumentacji ani założonej księgi wieczystej i w żaden sposób nie da się ustalić osób, którym przysługują prawa rzeczowe, przyjmuje się dane z katastru nieruchomości służące do jej oznaczenia.

\section{PROCEDURA WYWŁASZCZENIA}

Po nowelizacji art. 112 ust. 4 i art. 129 ust. 1 u.o.g.n. ustawą z dnia 24 lipca 1998 r. organem właściwym w sprawach wywłaszczenia i odszkodowania stał się starosta wykonujący zadania z zakresu administracji rządowej. W związku z tym, stosownie do art. 127 § $2 \mathrm{w}$ związku z art. 17 pkt 2 k.p.a., organem odwoławczym od decyzji w tych sprawach jest wojewoda ${ }^{18}$. Zgodnie $z$ art. $61 \S 1$ k.p.a. postępowanie administracyjne w sprawach wywłaszczenia wszczyna się z urzędu lub - w drodze wyjątku - na żądanie stron. Ponadto art. 115 ust. 1 u.o.g.n. konkretyzuje, że wszczęcie postępowania wywłaszczeniowego z urzędu następuje, jeżeli wywłaszczenie nieruchomości następuje na rzecz Skarbu Państwa, a na wniosek, jeżeli organ wykonawczy jednostki samorządu terytorialnego ubiega się o to na rzecz określonej jednostki samorządu terytorialnego. Podmioty inne niż gmina, powiat czy województwo mogą jedynie wychodzić z inicjatywą do organu wykonawczego właściwej jednostki samorządu terytorialnego do złożenia wniosku i wszczęcia postępowania wywłaszczeniowego ${ }^{19}$.

Po nowelizacji art. 115 ust. 1 u.o.g.n. w istotny sposób został zmieniony w 2003 r. sposób wszczęcia postępowania wywłaszczeniowego z urzędu. Wszczęcie postępowania z urzędu może nastąpić po złożeniu zawiadomienia przez podmiot, który zamierza realizować cel publiczny.

${ }^{17}$ Wyrok WSA w Kielcach z dnia 30 stycznia 2013 r., II SA/Ke 848/12, LEX nr 1298552.

18 T. Woś, Wywtaszczenie nieruchomości i ich..., s. 210.

19 Por. wyrok NSA - OZ we Wrocławiu z dnia 8 grudnia 1995 r., SA/Wr 120/95. ONSA 1997, nr 1, poz. 18 . 
W klasycznym ujęciu postępowanie wywłaszczeniowe można podzielić na trzy autonomiczne wobec siebie etapy. Po pierwsze, etap ustalenia przedmiotu, zakresu wywłaszczenia oraz jego niezbędności, zakończony orzeczeniem wywłaszczeniowym. Po drugie, etap ustalania wysokości i obowiązku wypłaty odszkodowania, zakończony orzeczeniem o odszkodowaniu. Po trzecie, etap wykonania wywłaszczenia kończący się wydaniem orzeczenia o jego wykonaniu ${ }^{20}$. Na podstawie art. 114 u.o.g.n., z zastrzeżeniem ust. 2 i 3, złożenie wniosku o wszczęcie postępowania wywłaszczeniowego należy poprzedzić rokowaniami o nabycie w drodze umowy praw określonych $\mathrm{w}$ art. 112 ust. 3, przeprowadzonymi między starostą a właścicielem lub użytkownikiem wieczystym nieruchomości, a także osobą posiadającą ograniczone prawo rzeczowe na tej nieruchomości. Na rzecz rokowań można zaoferować nieruchomość zamienną.

W sytuacji przeprowadzania wywłaszczenia nieruchomości na wniosek jednostki samorządu terytorialnego rokowania przeprowadzają właściwe organy wykonawcze. W przypadku, kiedy procedura ma dotyczyć nieruchomości o nieuregulowanym stanie prawnym, starosta podaje do wiadomości publicznej informację o zamiarze wywłaszczenia w myśl art. 114 ust. 3 u.o.g.n. Po upływie 2 miesięcy od dnia ogłoszenia starosty osoby, którym przysługują prawa rzeczowe na nieruchomości, mogą wszcząć postępowanie wywłaszczeniowe ${ }^{21}$. Jeżeli chodzi o wywłaszczenie nieruchomości o ustalonym stanie prawnym, ustawodawca $\mathrm{w}$ art. 114 u.o.g.n. przyznaje pierwszeństwo podjęcia próby nabycia praw rzeczowych do nieruchomości w drodze umowy jako aktu stanowiącego efekt zgodnej woli stron. Przedmiotem rokowań o zawarcie umowy z dotychczasowym podmiotem praw rzeczowych przysługujących mu do nieruchomości może być każda nieruchomość. Na tym etapie nie musi to być nieruchomość przeznaczona na cele publiczne. Dopiero, gdy w wyniku rokowań nie dojdzie do zawarcia stosownej umowy, może być wszczęte postępowanie wywłaszczeniowe, jeżeli nieruchomość przeznaczona jest na cel publiczny w miejscowym planie zagospodarowania przestrzennego lub została objęta decyzją o ustaleniu lokalizacji inwestycji celu publicznego ${ }^{22}$. Powyższe jest o tyle istotne, że dokumenty z rokowań stanowią dowód podjęcia próby ich przeprowadzenia i są one dołączane do wniosku o wywłaszczenie. Na podstawie tej dokumentacji organ mający przeprowadzić postępowanie wywłaszczeniowe dokonuje oceny, czy została spełniona ustawowa przesłanka dopuszczalności wszczęcia postępowania wywłaszczeniowego, czyli podjęcia przynajmniej próby przeprowadzenia rokowań z zachowaniem szczególnej staranności i poszanowaniem równości stron.

20 T. Woś, Wywłaszczenie nieruchomości i jej zwrot, Poznań 1995, s. 55.

${ }_{21}$ J. Jaworski, A. Prusaczyk, A. Tułodziecki, M. Wolanin, Ustawa o gospodarce nieruchomościami. Komentarz, Warszawa 2017.

${ }^{22}$ Ibidem. 
Nieprawidłowe przeprowadzenie rokowań, chociażby przez naruszenie równości stron w sposobie ustalenia terminu rokowań, w konsekwencji czego się nie odbędą, skutkuje niespełnieniem ustawowych przesłanek dopuszczalności wszczęcia postępowania wywłaszczeniowego. Powyższe negocjacje są uregulowane w art. 72 k.c., w myśl którego prowadzone są w celu zawarcia oznaczonej umowy, a umowa zostaje zawarta, kiedy strony dojdą do porozumienia co do wszystkich jej postanowień, które były przedmiotem rokowań. Przedmiotem rokowań powinny być zatem wszystkie istotne elementy przyszłej umowy, np.: określenie jej przedmiotu, terminu zawarcia, ceny bądź innej formy rozliczenia (jak np. nieruchomości zamiennej). Pozytywny wynik rokowań i zawarcie umowy pomiędzy stronami jest sposobem na uniknięcie przeprowadzania administracyjnego trybu wywłaszczenia nieruchomości.

Natomiast w przypadku upływu terminu 2 miesięcy na zawarcie umowy, wszczyna się postępowanie wywłaszczeniowe. Wszczęcie tego postępowania następuje $\mathrm{z}$ dniem doręczenia zawiadomienia stronom lub - w przypadku nieruchomości o nieuregulowanym stanie prawnym $-\mathrm{z}$ dniem określonym $\mathrm{w}$ ogłoszeniu o wszczęciu postępowania. Zgodnie $\mathrm{z}$ art. 130 u.o.g.n. starosta, wykonujący zadanie z zakresu administracji rządowej, składa w sądzie wniosek o ujawnienie w księdze wieczystej wszczęcia postępowania wywłaszczeniowego, a jeżeli nieruchomość nie ma założonej księgi wieczystej - o złożenie do istniejącego zbioru dokumentów zawiadomienia o wszczęciu tego postępowania. Po wszczęciu postępowania starosta, wykonujący zadanie z zakresu administracji rządowej, przeprowadza rozprawę administracyjną.

\section{ODSZKODOWANIE}

Odszkodowanie z tytułu pozbawienia lub ograniczenia prawa do nieruchomości, zgodnie z definicją wywłaszczenia nieruchomości, przysługuje z mocy prawa podmiotom do tego uprawnionym. Uprawnione w tym zakresie są osoby posiadające prawa rzeczowe do nieruchomości będącej przedmiotem wywłaszczenia. W myśl art. 130 u.o.g.n. odszkodowanie za wywłaszczenie nieruchomości powinno odpowiadać rynkowej wartości nieruchomości na dzień wydania decyzji o jej wywłaszczeniu, jeżeli wywłaszczenie polega na odebraniu praw do tej nieruchomości. Wartość nieruchomości jest określana według jej stanu także na dzień wydania decyzji o wywłaszczeniu. Istotne jest, aby zaznaczyć, że musi to być wartość nieruchomości na dzień wydania decyzji, a nie na dzień, w którym decyzja stała się ostateczna ${ }^{23}$. Wartość przedmiotu wywłaszczenia jest określana przez rzeczoznawcę majątkowego, który bierze pod uwagę takie elementy, jak: stan faktyczny, stan

\footnotetext{
${ }^{23}$ Ibidem.
} 
prawny i stan faktyczny otoczenia tej nieruchomości. W sprawach o wywłaszczenie rzeczoznawca majątkowy powoływany jest jako biegły z zakresu szacowania nieruchomości, co reguluje art. 84 ustawy z dnia 14 czerwca 1960 r. - Kodeks postępowania administracyjnego ${ }^{24}$. Organ właściwy do spraw z zakresu ustalenia odszkodowania orzeka na podstawie dowodu wartości danej nieruchomości, jaki stanowi operat szacunkowy sporządzony przez rzeczoznawcę majątkowego.

Powyższe stanowisko przyjmuje orzecznictwo Naczelnego Sądu Administracyjnego, który stanowi, że rzeczoznawca majątkowy z zakresu wyceny nieruchomości jest ekspertem w swojej dziedzinie i dysponuje odpowiednią wiedzą specjalistyczną, lecz nie zwalnia to właściwych organów administracji od obowiązku samodzielnej oceny wartości dowodowej operatu szacunkowego. Operat rzeczoznawcy majątkowego ma moc prawną opinii biegłego, o czym wspomniano wcześniej, zatem podlega swobodnej ocenie jako element zebranego materiału dowodowego ${ }^{25}$.

Wymienione wyżej elementy oceny wartości nieruchomości są kluczowe, ponieważ omawiane odszkodowanie przybiera formę rekompensaty utraty prawa własności i prawa użytkowania wieczystego, które określają wymienione współczynniki stanu nieruchomości. Ponadto art. 130 u.o.g.n. wskazuje również, że w kwestii ustalenia wysokości odszkodowania wymagane jest określenie przeznaczenia wywłaszczanej nieruchomości na podstawie planu miejscowego w myśl art. 15 ust. 2 pkt 1 u.o.p.z.p.

\section{ZWROT NIERUCHOMOŚCI}

W przypadku zmiany celu publicznego wywłaszczonej nieruchomości, czyli gdy staje się ona zbędna do realizacji tego celu, poprzedniemu właścicielowi przysługuje roszczenie o jej zwrot. Warunkiem zwrotu jest oddanie nabytego odszkodowania za wywłaszczenie. Co do zasady, uprawnieni do zwrotu wywłaszczonej nieruchomości są poprzedni właściciele lub ich spadkobiercy w terminie 3 miesięcy od dnia otrzymania zawiadomienia o możliwości zwrotu.

Art. 142 u.o.g.n. określa kompetencje starosty, wykonującego w tym zakresie zadania z zakresu administracji publicznej, który orzeka o rozliczeniach i terminach z tytułu zwrotu $w$ drodze decyzji zgodnie $\mathrm{z}$ art. 107 § 1 k.p.a. Na podstawie powyższej regulacji ustawodawca wskazał, że wniosek poprzedniego właściciela lub jego spadkobierców o zwrot nieruchomości wywłaszczonej powinien być złożony do starosty, który - po przeprowadzeniu stosownego postępowania administracyjnego - rozstrzyga w drodze decyzji o zwrocie nieruchomości, odmowie zwrotu

\footnotetext{
${ }^{24}$ Dz.U. z 2017 r., poz. 1257; Dz.U. z 2018 r., poz. 149.

25 Wyrok NSA z dnia 26 stycznia 2016 r., II OSK 459/05.
} 
lub umorzeniu postępowania ${ }^{26}$. Na podstawie art. 9a u.o.g.n. strona postępowania, niezadowolona z decyzji starosty, może złożyć odwołanie do wojewody, a następnie skargę do wojewódzkiego sądu administracyjnego. Istotne jest też to, że w tych sprawach, w których stroną postępowania jest gmina lub powiat, prezydent miasta na prawach powiatu, sprawujący funkcję starosty, podlega wyłączeniu na zasadach określonych w rozdziale V k.p.a., na co wskazuje art. 142 ust. 2 u.o.g.n.

Nieruchomość wywłaszczona podlega zwrotowi w stanie, w jakim jest w dniu jej zwrotu. Z powodu pogorszenia lub polepszenia jej stanu, a w rezultacie zmniejszenia lub zwiększenia wartości nieruchomości przez podjęte na niej działania przed wywłaszczeniem, wnioskodawca może ubiegać się o rozłożenie spłaty odszkodowania na raty. Wniosek składa podmiot uprawniony do ubiegania się o zwrot wywłaszczonej nieruchomości, a okres spłaty może trwać nie dłużej niż 10 lat²7.

\section{PODSUMOWANIE}

Wywłaszczenie nieruchomości w świetle obecnego stanu prawnego traktowane jest jako instytucja ultima ratio w odróżnieniu od ogólnych cywilnoprawnych zasad przenoszenia własności. Ustawodawstwo wywłaszczeniowe zawiera w swojej materii różnorodne rozwiązania prowadzące do wydania decyzji administracyjnej o wywłaszczeniu z poszanowaniem i ochroną prawa własności i innych praw rzeczowych obywateli. Ustawodawca przewidział możliwość zwrotu nieruchomości w sytuacji, kiedy cel publiczny, określony w decyzji administracyjnej, został zdezaktualizowany. Trybunał Konstytucyjny doprecyzował w wyroku z dnia 14 lipca 2015 r., że zwrot musi dotyczyć całości lub fizycznie wydzielonej części nieruchomości, jeżeli z wnioskiem o żądanie zwrotu występują wszyscy byli współwłaściciele lub ich spadkobiercy, nie zaś pojedyncze podmioty roszczące prawo co do swoich udziałów w tej nieruchomości ${ }^{28}$. Powyższy wyrok zlikwidował niespójność i wskazał, że nie można zwracać wywłaszczonej nieruchomości w częściach ułamkowych, bez zgody wszystkich byłych współwłaścicieli.

Państwo traktuje wywłaszczenie jako atrybut wykorzystywany w celu wykonywania własnych funkcji pro bono. Nie jest to inwazyjna ingerencja w prywatne prawa rzeczowe obywateli, ponieważ decyduje o tym szereg czynników natury ekonomicznej dla polepszenia warunków życia społeczeństwa. Ma to swoje odzwierciedlenie $\mathrm{w}$ ustawach będących lex specialis $\mathrm{w}$ stosunku do u.o.g.n., czego przykładem jest ustawa z dnia 27 października 1994 r. o autostradach płatnych

26 J. Jaworski, A. Prusaczyk, A. Tułodziecki, M. Wolanin, op. cit.

27 A. Jakubowska, Ustawa o gospodarce nieruchomościami z komentarzem oraz aktami szczegółowymi, Warszawa 2010, s. 117.

${ }_{28}$ Wyrok TK z dnia 14 lipca 2015 r., SK 26/14, Legalis. 
oraz Krajowym Funduszu Drogowym ${ }^{29}$, a także ustawa z dnia 28 marca 2003 r. o transporcie kolejowym ${ }^{30}$.

Na podstawie analizy obowiązujących przepisów dotyczących wywłaszczenia nieruchomości można stwierdzić, że regulacja jest zgodna z klauzulą demokratycznego państwa prawa zawartą w art. 2 Konstytucji RP, a w szczególności z zasadą zaufania do organów państwowych i stanowionego przez nie prawa.

\section{BIBLIOGRAFIA}

Babiarz S., Nieruchomości w prawie cywilnym, administracyjnym i podatkowym, t. 1, Warszawa 2016. Dydenko J., Telega T., Wycena nieruchomości. Komentarz do ustawy o gospodarce nieruchomościami oraz rozporządzenia Rady Ministrów w sprawie wyceny nieruchomości i sporządzenia operatu szacunkowego, Warszawa 2016.

Horoszko M., Gospodarka nieruchomościami. Komentarz, Warszawa 2014.

Jakubowska A., Ustawa o gospodarce nieruchomościami z komentarzem oraz aktami szczegółowymi, Warszawa 2010.

Jarosz-Żukowska S., Konstytucyjna zasada ochrony własności, Kraków 2003.

Jaworski J., Prusaczyk A., Tułodziecki A., Wolanin M., Ustawa o gospodarce nieruchomościami. Komentarz, Warszawa 2017.

Konstytucja Rzeczypospolitej Polskiej z dnia 2 kwietnia 1997 r. (Dz.U. z 1997 r., nr 78, poz. 483).

Protokół nr 1 z dnia 20 marca 1952 r. do Konwencji z dnia 4 listopada 1950 r. o ochronie praw człowieka i podstawowych wolności (Dz.U. z 1995 r., nr 36, poz. 175 ze zm.).

Stefańska E., [w:] S. Babiarz, Nieruchomości w prawie cywilnym, administracyjnym i podatkowym, t. 2, Warszawa 2017.

Strzelczyk R., Prawo nieruchomości, Warszawa 2016.

Szalewska M., Wywłaszczenie nieruchomości, Toruń 2005.

Ustawa z dnia 14 czerwca 1960 r. - Kodeks postępowania administracyjnego (Dz.U. z 2017 r., poz. 1257; Dz.U. z 2018 r., poz. 149).

Ustawa z dnia 23 kwietnia 1964 r. - Kodeks cywilny (Dz.U. z 2017 r., poz. 459, 933, 1132; Dz.U. z 2018 r., poz. 398).

Ustawa z dnia 29 grudnia 1989 r. o zmianie Konstytucji Rzeczypospolitej Ludowej (Dz.U. nr 75, poz. 444 ze zm.).

Ustawa z dnia 27 października 1994 r. o autostradach płatnych oraz Krajowym Funduszu Drogowym (Dz.U. z 2017 r., poz. 1057; Dz.U. z 2018 r., poz. 12, 138).

Ustawa z dnia 21 sierpnia 1997 r. o gospodarce nieruchomościami (Dz.U. z 2018 r., poz. 121).

Ustawa z dnia 27 marca 2003 r. o planowaniu i zagospodarowaniu przestrzennym (Dz.U. z 2017 r., poz. 1073, 1566).

Ustawa z dnia 28 marca 2003 r. o transporcie kolejowym (Dz.U. z 2017 r., poz. 2117).

Woś T., Wywłaszczenie nieruchomości i ich zwrot, Warszawa 2011.

Woś T., Wywłaszczenie nieruchomości i jej zwrot, Poznań 1995.

Wyrok NSA - OZ we Wrocławiu z dnia 8 grudnia 1995 r., SA/Wr 120/95. ONSA 1997, nr 1, poz. 18. Wyrok NSA z dnia 26 stycznia 2016 r., II OSK 459/05.

${ }^{29}$ Dz.U. z 2017 r., poz. 1057; Dz.U. z 2018 r., poz. 12, 138.

${ }^{30}$ Dz.U. z 2017 r., poz. 2117. 
Pobrane z czasopisma Studenckie Zeszyty Naukowe http://szn.umcs.pl

Data: 26/04/2023 12:16:04

Wyrok NSA - OZ w Krakowie z dnia 12 grudnia 2017 r., II SA/Kr 1010/00, ONSA 2001, nr 4, poz. 186.

Wyrok SN z dnia 2 lutego 2012 r., II CSK 265/11, LEX nr 1131118.

Wyrok TK z dnia 14 lipca 2015 r., SK 26/14, Legalis.

Wyrok WSA w Rzeszowie z dnia 6 grudnia 2012 r., II SA/Rz 826/12, LEX nr 134272.

Wyrok WSA w Kielcach z dnia 30 stycznia 2013 r., II SA/Ke 848/12, LEX nr 1298552.

\section{SUMMARY}

The aim of this study was to present the theory, procedure, and aspects of compensation resulting from the real estate compulsory purchase. Deprivation ownership right or another right to real estate can be realized only exclusively. The author formulates selected law regulations on rights of persons who where expropriation and specifics resolution based also on the practical application on the legislation. Attention was also paid to the international concept of real estate compulsory purchase and focuses on Polish legislation in development of the article.

Keywords: property expropriator; administrative decision; administrative trial; foreman; the Treasury; administrative hearing 